\title{
Synthesis and Thermotropic Properties of Some New Schiff Bases, $N$-[4-(4-n-Alkanoyloxybenzoyloxy)-2- Hydroxybenzylidene]-4-Cyano-, 4-Hydroxy-, 4-Thio- and 4-Nitroanilines
}

\author{
SIE-TIONG HA ${ }^{1, *}$, GUAN-YEOW YEAP ${ }^{2}$, AND PENG-LIM BOEY ${ }^{2}$ \\ ${ }^{1}$ Department of Chemical Science, Faculty of Science, Universiti Tunku Abdul Rahman, Jln \\ Universiti, Bandar Barat, Kampar, 31900 Perak, Malaysia \\ ${ }^{2}$ Liquid Crystal Research Laboratory, School of Chemical Sciences, Universiti Sains \\ Malaysia, 11800 Minden, Penang, Malaysia \\ hast@utar.edu.my \\ hast_utar@yahoo.com
}

Received 22 November 2011; Accepted 18 January 2012

\begin{abstract}
A series of elongated Schiff base esters containing three aromatic rings with hexadecanoyl chain as one of the terminal group and various $\mathrm{R}$ substituents $\left(\mathrm{R}=\mathrm{CN}, \mathrm{OH}, \mathrm{SH}\right.$, and $\left.\mathrm{NO}_{2}\right)$ at the other end of molecule were prepared, and their structures were confirmed via physical measurement. The thermotropic properties of these compounds were investigated via differential scanning calorimetry and polarizing optical microscopy. The thermal data indicate that all of these compounds exhibit mesomorphic properties. Whilst compounds with $\mathrm{R}=\mathrm{OH}, \mathrm{SH}$ and $\mathrm{NO}_{2}$ show nematic phases, compound containing cyano substituent are smectogenic in nature.
\end{abstract}

Keywords: Schiff bases, liquid crystal, thermotropic, smectic, nematic.

\section{Introduction}

Liquid crystalline materials have many practical applications in scientific and technological areas, in particular as display devices, organic light emitting diodes, anisotropic networks, photoconductors and semiconductor materials ${ }^{1-3}$. Strong demand of new liquid crystals (LCs) for applications has led to the preparation and study of numerous mesogens in particular, thermotropic $\mathrm{LCs}^{4,5}$. Most thermotropic liquid crystals are calamitic molecules having a rigid core consisted of two or more phenyl rings and one or more flexible terminal alkyl chains. Most of these studies focus mainly on Schiff's bases since the discovery of 4methoxybenzylidene-4'-butylaniline which exhibited a nematic phase at room temperature ${ }^{6}$. 
Recently, the mesomorphic properties of Schiff bases possessing two aromatic rings, $p$-noctadecanoyloxybenzylidene- $p$-substituted-anilines ${ }^{7,8}$ and $o$-n-hydroxy- $p$-nhexadecanoyloxybenzylidene-X-substituted-anilines ${ }^{9,10}$ (16A-X) have been reported. It was found that the rigidity of the Schiff base core system could be enhanced through the introduction of lateral hydroxyl group into the aldehyde fragment. Subsequent to this study, properties of three aromatic rings Schiff bases with higher molecule length-breadth ratio than the previous core system (two aromatic rings system) were investigated. These compounds were synthesized from the reaction of 4-(4-n-alkanoyloxybenzoyloxy)-2hydroxybenzaldehyde with a series of analogue anilines possessing substituents $\mathrm{R}=\mathrm{H}, \mathrm{F}$, $\mathrm{Cl}, \mathrm{Br}, \mathrm{OCH}_{3}, \mathrm{CH}_{3}$ and $\mathrm{C}_{2} \mathrm{H}_{5}$. This reaction led to the formation of mesogens showing SmA (where $\mathrm{R}=\mathrm{F}, \mathrm{Cl}$ and $\mathrm{Br}$ ) and nematic $(\mathrm{N})$ phases (where $\mathrm{R}=\mathrm{H}, \mathrm{OCH}_{3}, \mathrm{CH}_{3}$ and $\left.\mathrm{C}_{2} \mathrm{H}_{5}\right)^{11}$.

In order to accomplish the investigation upon the mesomorphism of the series consisting three aromatic rings core system, we continued with the other substituents ( $p-\mathrm{CN}$, $p$-OH, $p$-SH and $p-\mathrm{NO}_{2}$ ) positioned along the molecular long axis.

\section{Experimental}

4-Aminobenzonitrile, 4-aminophenol, 4-aminothiophenol, and 4-hydroxybenzoic acid were obtained from Merck (Germany). 2,4-Dihydroxybenzaldehyde was purchased from Acros Organics (USA). Whilst 4-nitroaniline and thionyl chloride were purchased from Riedel-de Haen (Germany), triethylamine was obtained from Fluka Chemie (Switzerland).

Analytical data were performed on Perkin Elmer 2400 LS series CHNS/O analyzers. Electron impact mass spectra (EI-MS) were recorded by Hewlett Packard 5989A Mass Spectrometer. FT-IR data were recorded on a Perkin Elmer 2000-FTIR spectrophotometer. NMR spectra were recorded in $\mathrm{CDCl}_{3}$ on a Bruker $400 \mathrm{MHz}$ Ultrashield Spectrometer.

The phase transition temperatures for the investigated compounds were determined using a differential scanning calorimetry (Shidmadzu DSC-50) which adopted a scanning rate of 2 ${ }^{\circ} \mathrm{C} / \mathrm{min}$. The optical microscopy studies were carried out with a Carl Zeiss polarizing microscope equipped with a Mettler FP52 hot stage. Phase identification was made by comparison of the observed texture with those reported in the literature ${ }^{12}$.

Molecular modeling study was performed using ACD Chemsketch Version 4.5. Geometrical optimization or energy minimization of the molecules was performed in order to gain an appreciation of molecular shape and geometry. The structural conformation obtained was subsequently used in calculating the polarizability of each compound as reported earlier ${ }^{9}$.

\section{Synthesis of Schiff Bases}

4-(4-n-Hexadecanoyloxybenzoyloxy)-2-hydroxybenzaldehyde, 1 was prepared by adapting a previously reported method ${ }^{11}$. Schiff bases 6-9 were synthesized by mixing equimolar amounts of compound $\mathbf{1}$ with the appropriate anilines, both dissolved in absolute ethanol. The reaction mixture was refluxed for three hours with stirring before it was filtered. The solvent was removed from the filtrate by evaporation. The light yellowish crystalline of Schiff bases 6-9 thus obtained was recrystallized from ethanol till the constant transition temperatures were obtained. The entire synthetic route is outlined in Figure 1. The elemental analysis, EI-MS, IR, NMR $\left({ }^{1} \mathrm{H}\right.$ and $\left.{ }^{13} \mathrm{C}\right)$ data are summarized as follow:

$N$-[4-(4-n-hexadecanoyloxybenzoyloxy)-2-hydroxybenzylidene]-4-cyanoaniline, 6

Yield 33\%. Found: C, 74.53; H, 7.39; N, 4.71. Cal. For $\mathrm{C}_{37} \mathrm{H}_{44} \mathrm{~N}_{2} \mathrm{O}_{5} ; \mathrm{C}, 74.47 ; \mathrm{H}, 7.43 ; \mathrm{N}$ 4.69. EI-MS m/z (rel. int \%): 596 (1) (M) ${ }^{+}$. IR (KBr): $v_{\max } / \mathrm{cm}^{-1} 3439$ (O-H), 2955, 2918, 
2849 (C-H aliphatic), $2226(\mathrm{C} \equiv \mathrm{N}), 1750\left(\mathrm{C}=\mathrm{O}\right.$ of $\mathrm{C}_{15} \mathrm{H}_{31} \mathrm{COO}$ - fragment), $1732(\mathrm{C}=\mathrm{O}$ of benzoate), $1623(\mathrm{C}=\mathrm{N}), 1600(\mathrm{C}=\mathrm{C}$ aromatic $), 1270(\mathrm{C}-\mathrm{O}) .{ }^{1} \mathrm{H}$ NMR $\left(400 \mathrm{MHz}, \mathrm{CDCl}_{3}\right): \delta$ 0.91 (t, 3H, $\left.\underline{\mathrm{H}}_{3}-\mathrm{CH}_{2}-\right)$, 1.29-1.46 (m, 24H, $\left.\mathrm{CH}_{3}-\left(\mathrm{C}_{2}\right)_{12}-\mathrm{C}_{2} \mathrm{H}_{4} \mathrm{COO}-\right)$, 1.80 (quint, $2 \mathrm{H}$, $\left.\mathrm{CH}_{2}-\mathrm{CH}_{2} \mathrm{COO}-\right), 2.62$ (t, 2H, - $\left.\underline{\mathrm{H}}_{2}-\mathrm{COO}-\right), 6.89$ (dd, $\left.1 \mathrm{H}, \mathrm{Ar}-\underline{\mathrm{H}}\right), 6.95(\mathrm{~d}, 1 \mathrm{H}, \mathrm{Ar}-\underline{\mathrm{H}}), 7.28$ (dd, 2H, Ar- $\underline{\mathrm{H}}), 7.35$ (d, 2H, Ar- $-\underline{\mathrm{H}}), 7.47$ (d, 1H, Ar- $-\underline{\mathrm{H}}), 7.73$ (d, 2H, Ar- $\underline{\mathrm{H}}), 8.23$ (dd, 2H, $\mathrm{Ar}-\underline{\mathrm{H}}), 8.62(\mathrm{~s}, 1 \mathrm{H}, \mathrm{CH}=\mathrm{N}), 12.89(\mathrm{~s}, 1 \mathrm{H}, \mathrm{O}-\mathrm{H}) .{ }^{13} \mathrm{C} \mathrm{NMR}\left(100 \mathrm{MHz}, \mathrm{CDCl}_{3}\right): 171.86(\mathrm{C}=\mathrm{O}$ of $\left.\mathrm{C}_{15} \mathrm{H}_{31} \mathrm{COO}-\right), 164.43(\mathrm{C}=\mathrm{O}$ of benzoate), $164.00(\mathrm{C}=\mathrm{N}), 110.76,111.13,113.79,117.25$, $122.31,122.41,126.88,132.19,133.91,134.23,152.61,155.71,155.95$ and 163.15 for aromatic carbons, $118.84(\mathrm{C} \equiv \mathrm{N}), 34.80,32.27,30.05,30.06,29.99,29.85,29.76,29.64$, $29.45,25.22,23.01$ and 14.39 for carbons in the alkyl chain $\left(\underline{\mathrm{C}}_{15} \mathrm{H}_{31} \mathrm{COO}-\right)$.

$\mathrm{N}$-[4-(4-n-hexadecanoyloxybenzoyloxy)-2-hydroxybenzylidene]-4-hydroxyaniline, 7

Yield 21\%. Found: C, 73.52; H, 7.80; N, 2.40. Cal. For $\mathrm{C}_{36} \mathrm{H}_{45} \mathrm{NO}_{6} ; \mathrm{C}, 73.57 ; \mathrm{H}, 7.72 ; \mathrm{N}$ 2.38. EI-MS m/z (rel. int \%): 587 (1) (M) ${ }^{+}$. IR (KBr): $v_{\max } / \mathrm{cm}^{-1} 3399(\mathrm{O}-\mathrm{H}), 2953,2919$, 2850 (C-H aliphatic), $1757\left(\mathrm{C}=\mathrm{O}\right.$ of $\mathrm{C}_{15} \mathrm{H}_{31} \mathrm{COO}$ - fragment $), 1741(\mathrm{C}=\mathrm{O}$ of benzoate $), 1619$ $(\mathrm{C}=\mathrm{N}), 1600\left(\mathrm{C}=\mathrm{C}\right.$ aromatic), $1261(\mathrm{C}-\mathrm{O}) .{ }^{1} \mathrm{H} \mathrm{NMR}\left(400 \mathrm{MHz}, \mathrm{CDCl}_{3}\right): \delta 0.91\left(\mathrm{t}, 3 \mathrm{H}, \mathrm{C}_{3^{-}}-\right.$ $\mathrm{CH}_{2}$ ) , 1.29-1.48 (m, 24H, $\left.\mathrm{CH}_{3}-\left(\mathrm{C}_{2}\right)_{12}-\mathrm{C}_{2} \mathrm{H}_{4} \mathrm{COO}-\right)$, 1.79 (quint, $2 \mathrm{H},-\mathrm{C}_{2}-\mathrm{CH}_{2} \mathrm{COO}-$ ), 2.62 (t, $\left.2 \mathrm{H},-\underline{\mathrm{C}}_{2}-\mathrm{COO}-\right), 6.87$ (m, $\left.2 \mathrm{H}, \mathrm{Ar}-\underline{\mathrm{H}}\right), 6.89$ (dd, 2H, Ar- $\left.\underline{\mathrm{H}}\right), 7.22$ (dd, 2H, Ar- $\underline{\mathrm{H}}$ ), 7.27 (dd, $2 \mathrm{H}, \mathrm{Ar}-\underline{\mathrm{H}}), 7.39$ (d, 1H, Ar- $\underline{\mathrm{H}}), 8.24(\mathrm{dd}, 2 \mathrm{H}, \mathrm{Ar}-\underline{\mathrm{H}}), 8.59(\mathrm{~s}, 1 \mathrm{H}, \mathrm{CH}=\mathrm{N}), 13.65(\mathrm{~s}$, brd, $1 \mathrm{H}, \mathrm{O}-\mathrm{H}) .{ }^{13} \mathrm{C}$ NMR $\left(100 \mathrm{MHz}, \mathrm{CDCl}_{3}\right): 171.98\left(\mathrm{C}=\mathrm{O}\right.$ of $\left.\mathrm{C}_{15} \mathrm{H}_{31} \mathrm{COO}-\right), 164.34(\mathrm{C}=\mathrm{O}$ of benzoate), $159.91(\mathrm{C}=\mathrm{N}), 110.86,113.09,116.58,117.88,122.25,122.76,127.12$, $132.20,133.20,141.66,154.65,155.44,155.60$ and 162.94 for aromatic carbons, 34.82, $32.26,30.03,30.06,30.03,29.98,29.83,29.74,29.63,29.45,25.22,23.01$ and 14.37 for carbons in the alkyl chain $\left(\underline{\mathrm{C}}_{15} \mathrm{H}_{31} \mathrm{COO}-\right)$.

$N$-[4-(4-n-hexadecanoyloxybenzoyloxy)-2-hydroxybenzylidene]- 4-thioaniline, $\boldsymbol{8}$

Yield 16\%. Found: C, 71.66; H, 7.43; N, 2.35. Cal. For $\mathrm{C}_{36} \mathrm{H}_{45} \mathrm{NO}_{5} \mathrm{~S} ; \mathrm{C}, 71.61 ; \mathrm{H}, 7.51 ; \mathrm{N}$ 2.32. EI-MS m/z (rel. int \%): $603(<1)(\mathrm{M})^{+}$. IR $(\mathrm{KBr}): v_{\max } / \mathrm{cm}^{-1} 3447(\mathrm{O}-\mathrm{H}), 2953,2917$, 2848 (C-H aliphatic), $1752\left(\mathrm{C}=\mathrm{O}\right.$ of $\mathrm{C}_{15} \mathrm{H}_{31} \mathrm{COO}$ - fragment $), 1742(\mathrm{C}=\mathrm{O}$ of benzoate $), 1622$ $(\mathrm{C}=\mathrm{N}), 1605\left(\mathrm{C}=\mathrm{C}\right.$ aromatic), $1283(\mathrm{C}-\mathrm{O}) .{ }^{1} \mathrm{H} \mathrm{NMR}\left(400 \mathrm{MHz}, \mathrm{CDCl}_{3}\right): \delta 0.91\left(\mathrm{t}, 3 \mathrm{H}, \mathrm{CH}_{3}-\right.$ $\mathrm{CH}_{2}$ ) , 1.29-1.51 (m, 24H, $\mathrm{CH}_{3}-\left(\mathrm{CH}_{2}\right)_{12}-\mathrm{C}_{2} \mathrm{H}_{4} \mathrm{COO}-$ ), 1.80 (quint, $2 \mathrm{H},-\mathrm{CH}_{2}-\mathrm{CH}_{2} \mathrm{COO}$ ), $2.62\left(\mathrm{t}, 2 \mathrm{H},-\mathrm{CH}_{2}-\mathrm{COO}-\right), 3.52(\mathrm{~s}, 1 \mathrm{H}, \mathrm{SH}), 6.86(\mathrm{dd}, 1 \mathrm{H}, \mathrm{Ar}-\underline{\mathrm{H}}), 6.92(\mathrm{~d}, 1 \mathrm{H}, \mathrm{Ar}-\underline{\mathrm{H}}), 7.20$ (dd, 2H, Ar- $-\underline{H}), 7.27$ (m, 2H, Ar- $\underline{\mathrm{H}}), 7.35$ (dd, 2H, Ar- $-\underline{\mathrm{H}}), 7.44$ (dd, 1H, Ar- $\underline{\mathrm{H}}), 8.24$ (dd, 2H, $\mathrm{Ar}-\underline{\mathrm{H}}), 8.63(\mathrm{~s}, 1 \mathrm{H}, \mathrm{CH}=\mathrm{N}), 13.37$ (s, brd, $1 \mathrm{H}, \mathrm{O}-\mathrm{H}) .{ }^{13} \mathrm{C}$ NMR $\left(100 \mathrm{MHz}, \mathrm{CDCl}_{3}\right): 171.87$ $\left(\mathrm{C}=\mathrm{O}\right.$ of $\left.\mathrm{C}_{15} \mathrm{H}_{31} \mathrm{COO}-\right), 164.12(\mathrm{C}=\mathrm{O}$ of benzoate $), 161.64(\mathrm{C}=\mathrm{N}), 110.94,113.32,117.66$, $122.32,122.24,127.04,131.02,132.29,132.18,133.65,146.57,155.15,155.62,163.01$ for aromatic carbons, 34.81, 32.26, 30.03, 30.06, 30.05, 29.99, 29.85, 29.76, 29.64, 29.45, $25.22,23.09$ and 14.52 for carbons in the alkyl chain $\left(\underline{\mathrm{C}}_{15} \mathrm{H}_{31} \mathrm{COO}-\right)$.

N-[4-(4-n-hexadecanoyloxybenzoyloxy)-2-hydroxybenzylidene]-4-nitroaniline, 9

Yield 14\%. Found: C, 70.15; H, 7.23; N, 4.51. Cal. For $\mathrm{C}_{36} \mathrm{H}_{44} \mathrm{~N}_{2} \mathrm{O}_{7} ; \mathrm{C}, 70.11 ; \mathrm{H}, 7.19 ; \mathrm{N}$ 4.54. EI-MS m/z (rel. int \%): $616(<1)(\mathrm{M})^{+}$. IR $(\mathrm{KBr}): v_{\max } / \mathrm{cm}^{-1} 3457(\mathrm{O}-\mathrm{H}), 2954,2916$, 2848 (C-H aliphatic), $1747\left(\mathrm{C}=\mathrm{O}\right.$ of $\mathrm{C}_{15} \mathrm{H}_{31} \mathrm{COO}$ - fragment $), 1732(\mathrm{C}=\mathrm{O}$ of benzoate $), 1624$ $(\mathrm{C}=\mathrm{N}), 1604\left(\mathrm{C}=\mathrm{C}\right.$ aromatic), $1277(\mathrm{C}-\mathrm{O}) .{ }^{1} \mathrm{H} \mathrm{NMR}\left(400 \mathrm{MHz}, \mathrm{CDCl}_{3}\right): \delta 0.91\left(\mathrm{t}, 3 \mathrm{H}, \mathrm{C}_{3^{-}}\right.$$\mathrm{CH}_{2}$ ), $1.29-1.46$ (m, 24H, $\mathrm{CH}_{3}-\left(\mathrm{CH}_{2}\right)_{12}-\mathrm{C}_{2} \mathrm{H}_{4} \mathrm{COO}-$ ), 1.80 (quint, $2 \mathrm{H},-\mathrm{C}_{2}-\mathrm{CH}_{2} \mathrm{COO}-$ ), 2.62 (t, 2H, $\left.-\mathrm{CH}_{2}-\mathrm{COO}-\right), 6.90$ (dd, $\left.1 \mathrm{H}, \mathrm{Ar}-\underline{\mathrm{H}}\right), 6.96$ (d, 1H, Ar- $\left.\underline{\mathrm{H}}\right), 7.28$ (m, $\left.2 \mathrm{H}, \mathrm{Ar}-\underline{\mathrm{H}}\right), 7.39$ $(\mathrm{d}, 2 \mathrm{H}, \operatorname{Ar}-\underline{\mathrm{H}}), 7.50(\mathrm{~d}, 1 \mathrm{H}, \mathrm{Ar}-\underline{\mathrm{H}}), 8.25(\mathrm{dd}, 2 \mathrm{H}, \mathrm{Ar}-\underline{\mathrm{H}}), 8.33(\mathrm{~d}, 2 \mathrm{H}, \mathrm{Ar}-\underline{\mathrm{H}}), 8.66(\mathrm{~s}, 1 \mathrm{H}$, $\mathrm{CH}=\mathrm{N}), 12.82(\mathrm{~s}, 1 \mathrm{H}, \mathrm{O}-\mathrm{H}) \cdot{ }^{13} \mathrm{C}$ NMR $\left(100 \mathrm{MHz}, \mathrm{CDCl}_{3}\right): 171.86\left(\mathrm{C}=\mathrm{O}\right.$ of $\left.\mathrm{C}_{15} \mathrm{H}_{31} \mathrm{COO}-\right)$, $164.79(\mathrm{C}=\mathrm{O}$ of benzoate $), 163.63(\mathrm{C}=\mathrm{N}), 111.20,113.89,122.22,122.31,125.58,126.64$, $125.58,132.23,155.81,157.99,163.22$, for aromatic carbons, 34.80, 32.26, 30.03, 30.07, 
$30.03,29.97,29.82,29.45,29.63,29.45,25.21,23.01$ and 14.28 for carbons in the alkyl chain $\left(\underline{\mathrm{C}}_{15} \mathrm{H}_{31} \mathrm{COO}-\right)$.

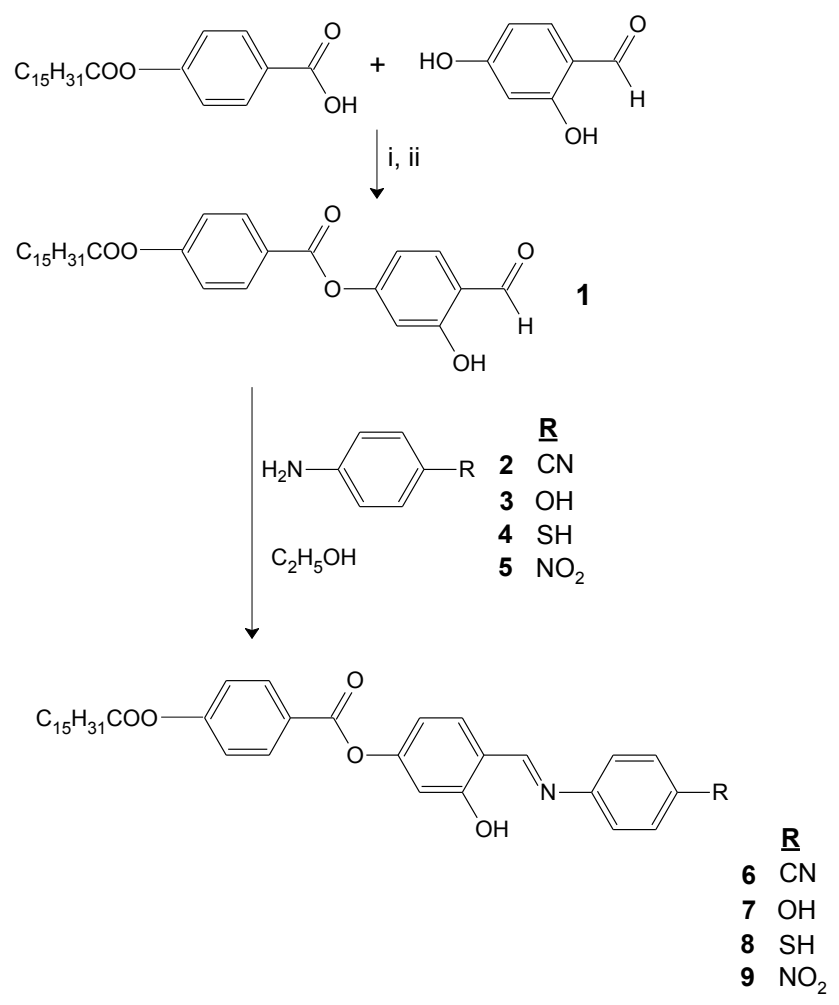

Figure 1. Synthetic routes towards the formation of intermediates and target compounds 69. Reagent and conditions: (i) $\mathrm{SOCl}_{2}$, reflux for 3 hours; (ii) anhydrous $\mathrm{CH}_{2} \mathrm{Cl}_{2}, \mathrm{DMF}$, $\left(\mathrm{C}_{2} \mathrm{H}_{5}\right)_{3} \mathrm{~N}, \mathrm{~N}_{2}$ atmosphere, reflux for 5 hours.

\section{Results and Discussion}

The percentages of $\mathrm{C}, \mathrm{H}$ and $\mathrm{N}$ from the elemental analysis agreed with the calculated values for compounds 6-9. The molecular ion peaks $\left(\mathrm{M}^{+}\right)$obtained from the mass spectrometry analyses were also in accordance with the theoretical values. The diagnostic bands observable via the IR analysis are characteristic of the structure properties of title compounds. All ${ }^{1} \mathrm{H}$ and ${ }^{13} \mathrm{C}$ NMR data further verify the identification of each molecule in $\mathrm{CDCl}_{3}$ of which the assignment of peaks agree with the respective formulation of compounds 6-9.

Phase Transition Behaviour and Liquid Crystallinity of N-[4-(4-n-

hexadecanoyloxybenzoyloxy)-2-hydroxybenzylidene]-4-cyano-, 4-hydroxy-, 4-thio- and 4-

nitroanilines

The phase transition temperatures, associated enthalpy $(\Delta H)$ and associated entropy $(\Delta S)$ values of all title compounds are tabulated in Table 1. All of the phase transition 
temperatures evaluated on the basis of texture change is in good accordance with those measured by DSC. Enthalpy values of the various phase transitions agree well with the existing related literature values ${ }^{13}$ which in fact has helped in further confirmation of the mesophase type. It is clearly shown (Table 1) that upon heating all compounds exhibit endotherms characteristic of the crystal-mesophase and mesophase-isotropic transitions at temperature greater than melting temperature $\left(\mathrm{T}_{\mathrm{m}}\right)$.

Table 1. Transition Temperatures, Associated Enthalpy and Entropy Changes of

Compounds 6-9.

\begin{tabular}{|c|c|c|c|c|}
\hline Compound & Transition & $\mathrm{T} /{ }^{\circ} \mathrm{C}$ & $\begin{array}{c}\Delta H / \\
\mathrm{kJ} \mathrm{mol}^{-1}\end{array}$ & $\begin{array}{c}\Delta S / \\
\left(10^{-3}\right) \mathrm{kJ} \mathrm{K}^{-1} \mathrm{~mol}^{-1}\end{array}$ \\
\hline \multirow{3}{*}{$\mathbf{6}$} & $\mathrm{Cr}-\mathrm{SmA}$ & 104.5 & 35.6 & 94.30 \\
\cline { 2 - 5 } & $\mathrm{SmA}-\mathrm{I}$ & 236.0 & 2.3 & 4.52 \\
\hline \multirow{4}{*}{} & $\mathrm{Cr}_{1}-\mathrm{Cr}_{2}$ & 122.9 & 1.0 & 2.53 \\
\cline { 2 - 5 } & $\mathrm{Cr}_{2}-\mathrm{N}$ & 150.0 & 25.1 & 59.34 \\
\cline { 2 - 5 } & $\mathrm{N}-\mathrm{I}$ & 215.4 & 5.8 & 11.88 \\
\hline \multirow{4}{*}{8} & $\mathrm{Cr}_{1}-\mathrm{Cr}_{2}$ & 105.8 & 37.7 & 99.52 \\
\cline { 2 - 5 } & $\mathrm{Cr}_{2}-\mathrm{Cr}_{3}$ & 122.4 & 3.0 & 7.59 \\
\cline { 2 - 5 } & $\mathrm{Cr}_{3}-\mathrm{N}$ & 170.2 & 10.0 & 22.56 \\
\cline { 2 - 5 } & $\mathrm{N}-\mathrm{I}$ & $197.6^{\mathrm{a}}$ & - & - \\
\hline \multirow{2}{*}{$\mathbf{9}$} & $\mathrm{Cr}-\mathrm{N}$ & 86.8 & 49.6 & - \\
\cline { 2 - 5 } & $\mathrm{N}-\mathrm{I}$ & $210.3^{\mathrm{a}}$ & - & 137.9 \\
\hline
\end{tabular}

${ }^{\mathrm{a}}$ Polarized optical microscopy data $\mathrm{Cr}_{1}$ and $\mathrm{Cr}_{2}$, crystal; SmA, smectic A; N, nematic; I, isotropic.

Under microscope study of compound 6 during slow cooling from isotropic, it was observed that $\mathrm{SmA}$ phase grows as filaments which coalesce to form a focal-conic fan texture on further cooling. The emergence of enantiotropic SmA phase is found to be in agreement with its analogue $o$-n-hydroxy- $p$-n-hexadecanoyloxybenzylidene- $p$-cyanoanilines (16-CN) as that reported earlier ${ }^{10}$. Figure $2 \mathrm{a}$ shows the filament growth pattern appearing below the isotropic. The filaments increase in length but not growing in terms of diameter. During this growth process, the filaments buckle quasi-continuously, leading to a snake-like appearance. These filaments are metastable, and eventually coalesced to form focal-conic shapes. Naito et $a l .{ }^{14}$ have developed a theory in which the filamentary structure is regarded as a smectic A tube, consisting of concentric cylindrical smectic layers. This theory explains current observations, namely that the growth has strong temperature dependence during the cooling process, and that once the filaments have grown up to a certain length (called the threshold length in the theory) buckling occurs. The filamentary growth is generally occured for binary/ternary mixtures ${ }^{15,16}$, although as here, Arora et al. ${ }^{17}$ and Yelamaggad et al. ${ }^{18}$ have reported it in a single component. It is possible that this type of growth is observed when the system has a 'structural degrees of freedom' (as in mixtures) or 'configurational degrees of freedom' (as in the present system). In the cyano compounds, there is a strong tendency to form an antiparallel dimer due to a strong dipole-dipole interaction and form bilayer arrangements of smectic A phase $e^{7,19}$. The presence of bilayer arrangements in compound 6 probably induced the filamentary structure wherein each cyano group in a pair is located close to the opposite end of its neighbour wherein the dimerization occurs by interaction of two cyano groups. The lateral interaction between one cyano group of a molecule with another cyano group of another molecule is probably weak. Thus, the intermolecular 
bonding formed between two cyano groups is very flexible and hence, the filament (or tube) formed from the dimerization will buckle freely leading to a snake-like appearance.

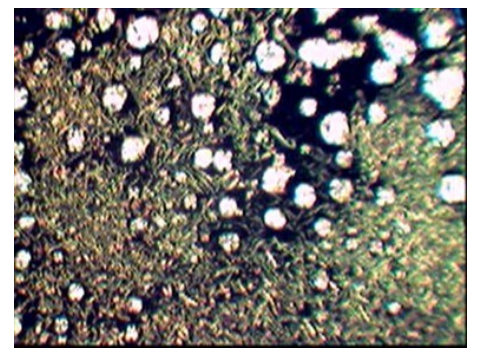

(a)

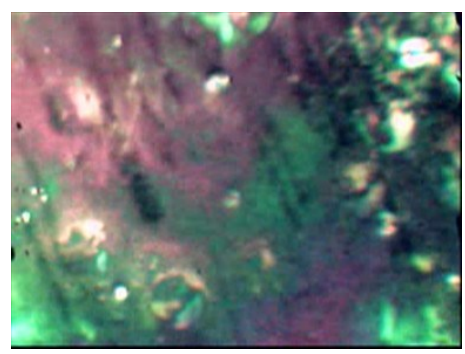

(b)

Figure 2. (a) Optical photomicrograph of the filaments texture observed at $230{ }^{\circ} \mathrm{C}$ at a cooling rate of $0.1{ }^{\circ} \mathrm{C} \mathrm{min}{ }^{-1}$ of the $\mathrm{SmA}$ phase developing from the isotropic phase, for compound 6. (b) Optical photomicrograph of compound 7 exhibiting nematic phase.

Observation under POM upon compounds 7, 8 and 9 during melting process exhibit schlieren threaded or marble texture typical of a nematic phase. Figure $2 b$ shows the representative optical photomicrograph of compound 7 displaying nematic phase. Compound 7 also showed an endotherm in the DSC thermogram (Table 1) before the crystal-nematic transition at $122.9{ }^{\circ} \mathrm{C}$. The texture observed under the microscope is indicative of the presence of subphases within the crystal phase $\left(\mathrm{Cr}_{1}-\mathrm{Cr}_{2}\right)$ which resembles the phenomena reported in ortho-hydroxy-para-hexadecanoyloxybenzylidene-parasubstituted-anilines ${ }^{9,10}$. Similar characteristic was observed for compound $\mathbf{8}$.

The mesomorphic properties of compounds 6-9 were compared with the analogue compounds, $o$-n-hydroxy- $p$-n-hexadecanoyloxybenzylidene-X-substituted anilines ${ }^{10}(16-\mathrm{X})$, in which $\mathrm{X}$ is the substituent of $\mathrm{CN}, \mathrm{OH}, \mathrm{SH}$ and $\mathrm{NO}_{2}$. Compounds 6-9 are found to be different from those reported analogue compounds due to additional aromatic ring joined to the benzylideneaniline system via ester bond. Therefore, it has been presumed to change the characteristic of the benzylideneaniline skeleton whereby the molecule increases with little or no change in the width. These two factors allow an increase in the anisotropy of the molecule. Thus, the polarizability of the molecules in compounds 6-9 is expected to rise. This has also been confirmed by the polarizability values wherein the calculated polarizability (Table 2) of compound $6,7,8$ and 9 are higher than those values reported in the series of $16-\mathrm{X}$ of which $16-\mathrm{CN}\left[(56.92 \pm 0.5) \times 10^{-24} \mathrm{~cm}^{3}\right], 16-\mathrm{OH}\left[(54.67 \pm 0.5) \times 10^{-24}\right.$ $\left.\mathrm{cm}^{3}\right], 16-\mathrm{SH}\left[(57.24 \pm 0.5) \times 10^{-24} \mathrm{~cm}^{3}\right]$ and $16-\mathrm{NO}_{2}\left[(56.58 \pm 0.5) \times 10^{-24} \mathrm{~cm}^{3}\right]$, respectively. As a consequence, the clearing temperature of compounds 6-9 is comparatively higher than those values reported for the analogue compounds.

Table 2. Polarizability (calculated value) for compounds 6-9.

\begin{tabular}{|c|c|}
\hline Compound & $\begin{array}{c}\text { Polarizability } \\
\left(\alpha \pm 0.5 \times 10^{-24} \mathrm{~cm}^{3}\right)\end{array}$ \\
\hline $\mathbf{6}$ & 69.59 \\
\hline $\mathbf{7}$ & 67.34 \\
\hline $\mathbf{8}$ & 69.91 \\
\hline $\mathbf{9}$ & 69.25 \\
\hline
\end{tabular}




\section{Conclusions}

$N$-[4-(4- $n$-hexadecanoyloxybenzoyloxy)-2-hydroxybenzylidene]-4-substituted-anilines exhibited smectic A phase for cyano substituent and nematic phase for $\mathrm{OH}, \mathrm{SH}$ and $\mathrm{NO}_{2}$ groups. The clearing temperatures of title compounds have increased with the enhanced length-breadth ratio.

\section{Acknowledgement}

The authors would like to thank Universiti Tunku Abdul Rahman and Universiti Sains Malaysia for the research facilities and financial supports.

\section{References}

1. Petti L, Rippa M, Fiore A, Manna L and Mormile P, Opt. Mater. 2010, 32, 1011.

2. Shurpo N A, Vakshtein M S and Kamanina N V, Tech. Phys. Lett. 2010, 36, 319.

3. Hoang M H, Cho M J, Kim K H, Lee T W, Jin J I and Choi D H, Chem. Lett. 2010, 39, 396.

4. Yuksel F, Atilla D and Ahsen V Polyhedron. 2007, 26, 4551..

5. Zhang B Y, Meng F B, Tian M and Xiao W Q, React. Funct. Polym. 2005, 66, 551.

6. Kelker H. and Scheurle B, Angewandte Chemie International Edition, 1969, 8, 884.

7. Yeap G Y, Ooi W S, Nakamura Y and Cheng Z, Molecular Crystals Liquid Crystals, 2002, 381, 169.

8. Yeap G Y, Ha S T, Lim P L, Boey P L, Mahmood W A K, Ito M M and Sanehisa S, Molecular Crystals Liquid Crystals, 2004, 423, 73.

9. Yeap G Y, Ha S T, Lim P L, Boey P L, Ito M M, Sanehisa S and Vill V, Molecular Crystals Liquid Crystals, 2006, 452, 63.

10. Ooi W S, Master of Science Thesis, Universiti Sains Malaysia, Malaysia, 2003.

11. Ha S T, Yeap G Y and Boey P L, Res. J. Chem. Environ., 2011, 15(2), 677.

12. Demus D and Richter L, Textures of Liquid Crystals, Verlag Chemie, New York.

13. Yeap G Y, Ha S T, Lim P L, Boey P L, Ito M M, Sanehisa S and Youhei Y, 2006, Liquid Crystals, 33(2), 205.

14. Naito H., Okuda M and Zhong-Can O Y, Phys. Rev. E., 1997, 55(2), 1655.

15. Pratibha R and Madhusudana N V, Journal de Physique II, 1992, 2, 383.

16. Adamczyk A, Molecular Crystals Liquid Crystals, 1995, 261, 271.

17. Arora S L, Palffy-Muhoray P and Vora R A, Liquid Crystals, 1989, 5(1), 133.

18. Yelamaggad C V, Mathews M, Hiremath U, Nair G, Shankar Rao D S and Prasad S K, Liquid Crystals, 2003, 30(8), 899.

19. Gray G W and Goodby J W, Smectic Liquid Crystals, Heydon \& Sons Inc., Philadephia, 1984. 


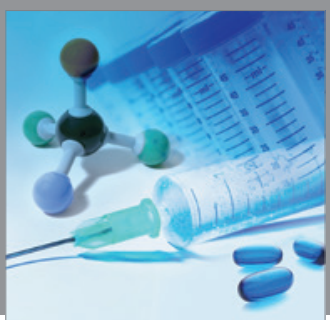

International Journal of

Medicinal Chemistry

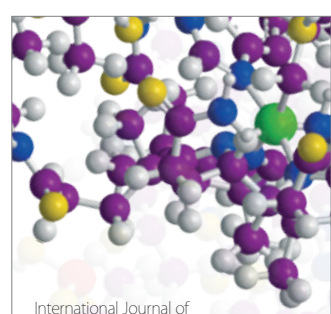

Carbohydrate Chemistry

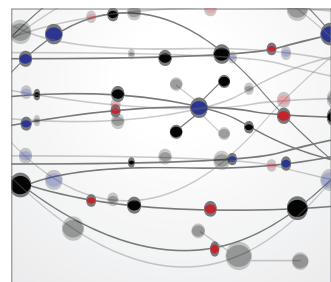

The Scientific World Journal
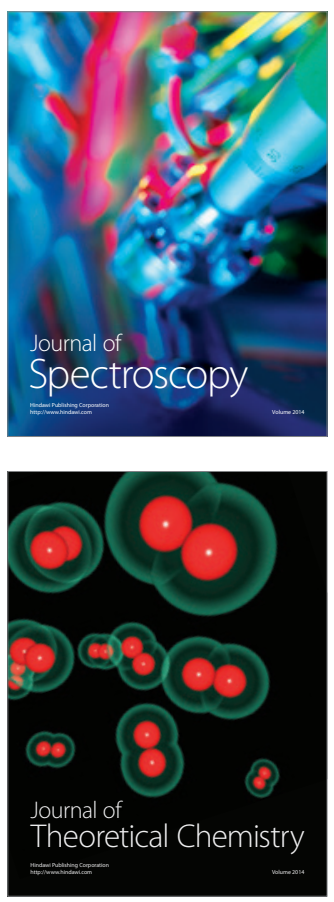
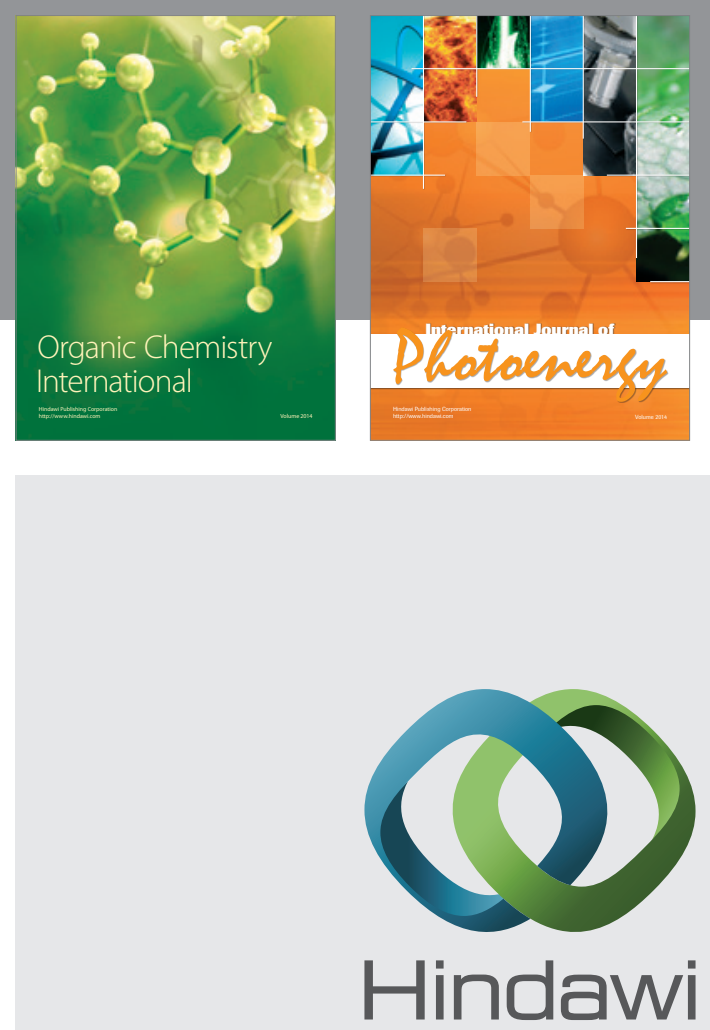

Submit your manuscripts at

http://www.hindawi.com
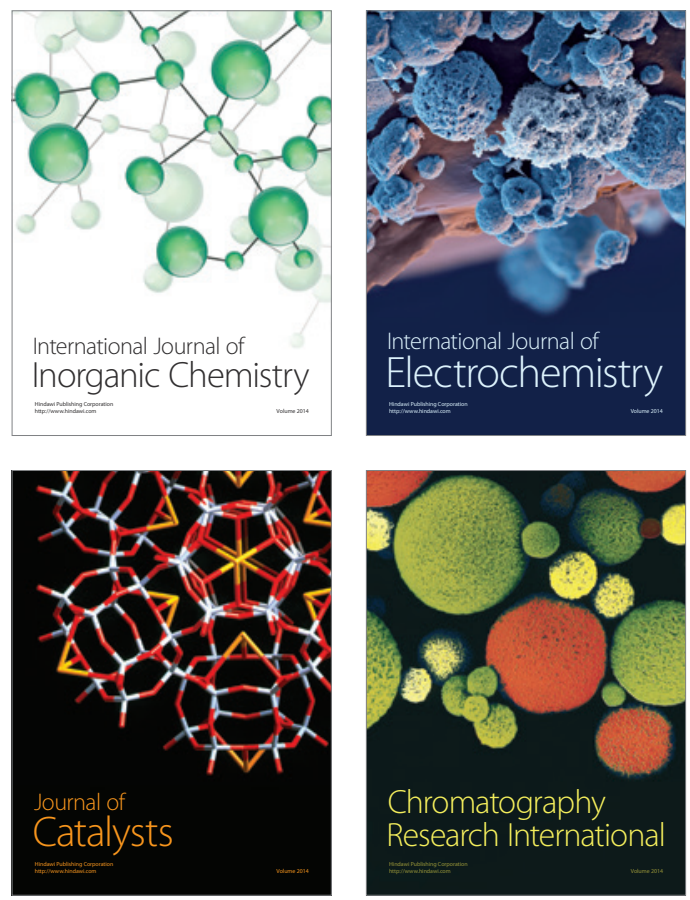
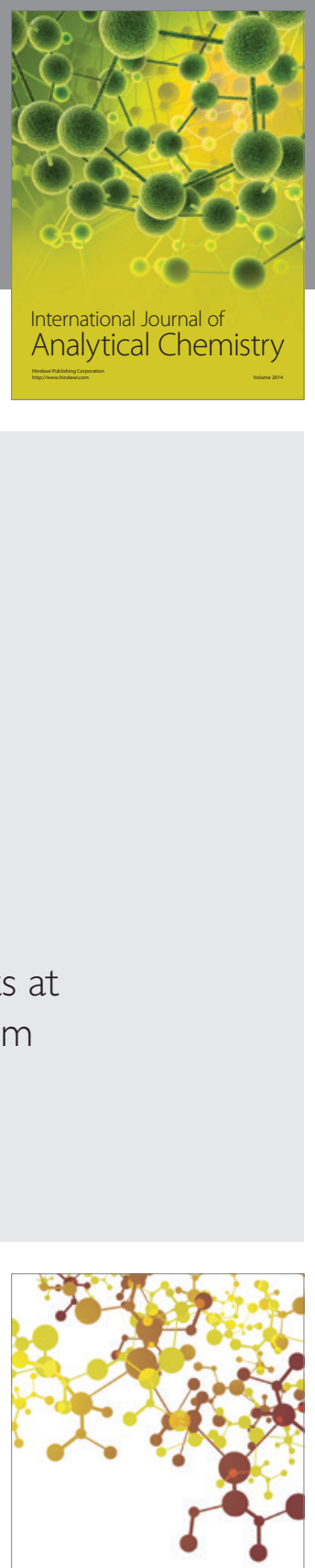

Journal of

Applied Chemistry
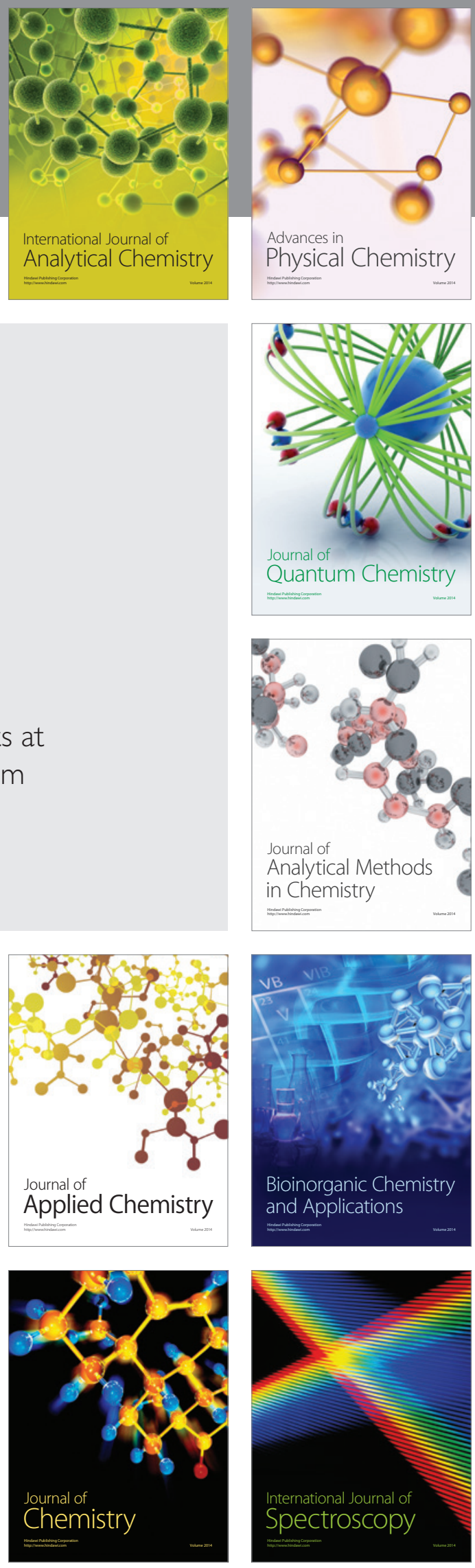